\title{
AN ANNOTATED LIST OF THE CYPRINODONT FISHES OF HISPANIOLA, WITH DESCRIPTIONS OF TWO NEW SPECIES ${ }^{1}$
}

\author{
GEORGE S. MYERS \\ United States National Museum
}

(Figs. 273-279 incl.)

The cyprinodont fishes obtained in Haiti by Dr. William Beebe and Mr. John Tee-Van in 1927 were turned over to the writer for study in connection with his work on the fishes of Hispaniola. Since the final paper revising and illustrating the fresh-water fish fauna of the island will be still further delayed, it seems best at this time to list the known species of the cyprinodonts and bring together the rather scattered recent literature on the group. In listing the species I have briefly recorded the specimens obtained by Dr. Beebe's expedition. The full data on this material will be set forth later in my monograph.

Besides the cyprinodonts, the fresh-water fish fauna of Hispaniola includes only one (or perhaps two) cichlids, an Agonostomus, and a few gobies. Since the marine fishes and the cichlids have already been covered in other papers in this volume of ZooLOGICA, the present contribution practically completes the list of the known fishes of the island.

I wish to thank Dr. Beebe and Mr. Tee-Van for the use of their important material and for their interest and help. The figures illustrating the paper were made by Mr. Pablo L. Bravo. The drawings of Mollienisia dominicensis and Limia dominicensis were made at the expense of the United States National Museum.

\section{Family CyPRINODONTIDAE \\ Subfamily Fundulinae \\ Genus Rivulus Poey}

\section{Rivulus heyei Nichols}

Rivulus heyei Nichols, 1914, p. 143 (Saona Isl.); Myers, 1925, p. 370 (on holotype); Myers, 1927, p. 123 (name only).

This species is as yet known only from the holotype, $20 \mathrm{~mm}$. long, and not in particularly good condition. Mr. Nichols tells me that the specimen was found swimming in the camp water-bucket by $\mathrm{Mr}$. de Booy while he was camping on Saona Island, off the southeastern coast of Hispaniola. If it were not for the fact that this detail of the collecting is remembered, I should be inclined to doubt the locality, since Rivulus has never been taken on Hispaniola itself. However, the various species of the genus are very secretive, usually inhabiting masses of vegetation in very small bodies of

1 Published by permission of the Secretary of the Smithsonian Institution.

Contribution No. 476, Department of Tropical Research, New York Zoological Society. 
water. Search should be made for Rivulus in such places all over the main island.

$R$. heyei is not well distinguished from the Cuban $R$. cylindraceus and more material must be secured before its systematic status is clear.

\section{Subfamily Cyprinodontinae \\ Genus Cyprinodon Lacépède}

I have experienced some difficulty in attempting to determine the position of a species, described below as Cyprinodon bondi, in accordance with Hubbs' key to the genera of American Cyprinodontinae (Hubbs, 1926, p. 16). It soon became apparent that some of the characters used by Hubbs to separate his new genus Floridichthys from Cyprinodon were not constant, but that others not hitherto noticed set Floridichthys apart as a very distinct genus. My difficulty was caused by the fact that adults of bondi, although the fish is undoubtedly a member of the genus Cyprinodon, agree with most of the key characters given by Hubbs for Floridichthys. I give revised definitions of the two genera below.

\section{Cyprinodon}

1. Nearly all of the preorbital area (excepting the upper part, on a level with the nostrils) scaly, the free edges of the scales directed upward; squamation always rising in front above level of lower part of eye.

2. Anterior edge of squamation of top of snout formed of several scales which are usually somewhat irregular, leaving a variable (usually rather narrow) naked area between them and the premaxillary groove.

3. Scaly flap separating pelvic fins usually short and somewhat irregular; it is composed of one or two distal scales and two to five basal scales, all of which are to some degree asymmetrical.

4. Inner border of iris smoothly oval.

5. Dorsal fin of adult males smaller and higher, the last two rays much shorter than the longest anterior ones.

6. Caudal peduncle either somewhat slender throughout or else deep anteriorly and constricted at caudal base.

7. Scales rather thin and squamation in general less regular; dorsal origin more posterior; almost always an ocellus or dark spot on the basal part of the last dorsal rays in the female.

\section{Floridichthys}

1. Preorbital area naked above a line running down from the lower part of the orbit to the lower part of the maxillary; anterior cheek squamation not rising above level of lower part of eye.

2. Anterior edge of squamation of top of snout formed of one broad, regular plate, emarginate in front, covering nearly whole width of snout, and leaving a rather wide naked area between it and the premaxillary groove.

3. Scaly flap separating pelvic fins long, strictly regular, and symmetrical, composed of two large, wide, regular scales in tandem order, the distal one elongated.

4. A small, pointed projection of the iris extending down over the upper part of the pupil of the eye.

5. Profile of erected dorsal fin of adult males lower and more broadly rounded, the last two rays almost as long as the highest anterior ones.

6. Caudal peduncle uniformly very deep. 
7. Squamation heavy and very regular; dorsal origin more anterior; no ocellus or dark spot on the basal part of the last dorsal rays in the female.

From the above it will be seen that I have totally abandoned the enlargement of the humeral scale, the restriction of the branchial apertures, and the ciliation of the scales as differences between these two genera. In $C$. bondi the humeral scale of the adult is not normally enlarged, although a few specimens show it and it is always more or less evident in the young. The branchial openings of bondi are as large as those of carpio, the genotype of Floridichthys, and there is little difference between bondi and certain other species of Cyprinodon (elegans, macularius) in this character. Adult male bondi do not show the ciliation of the scales of other forms of Cyprinodon, except slightly on the cheek, where the ctenii are usually strongest.

Jordanella agrees with Cyprinodon rather than with Floridichthys in the frontal and preorbital squamation, but differs from both in the greatly reduced (and sometimes absent) scaly flap between the pelvics. Further, Jordanella does not show the peculiar tongue of iris, and I believe that, on the whole, it is much more closely related to Cyprinodon than to Floridichthys. The Old World genus Aphanius is very close to Cyprinodon but differs, besides the elongate form, in the more weakly united premaxillaries. The surfaces at the point of junction are small, and the median, posteriorly directed, premaxillary processes are decidedly narrower than in the American genus. Tellia, from the Atlas region of northwest Africa, is said to differ from "Cyprinodon" (equals Aphanius) only in the absence of pelvic fins, a character of doubtful value since Cyprinodon macularius often (and C. diabolis almost always) lacks these fins. I have seen no material of Tellia, but the published figures lead me to suspect that it is not as close to Aphanius as has been supposed. Its body and head form, though shorter, reminds one of Empetrichthys, and its pharyngeals and other characters need reexamination.

\section{Cyprinodon bondi, new species}

Diagnosis: A very large Cyprinodon, the adults reaching at least 82 $\mathrm{mm}$. total length, this being in excess of any known member of the genus. It is remarkably different from all others known to me in the large size, high scale count (28 to 30 to end of hypural), the lack of enlargement of the humeral scale in the adult, the long straight predorsal profile, and the slightly emarginate (or at least very sharply truncate) caudal fin.

Holotype: U.S.N.M. 100960. Adult female, $66 \mathrm{~mm}$. standard length, $82 \mathrm{~mm}$. total. Étang Saumâtre, Haiti, Feb. 20, 1933. R. M. Bond.

PARATYPES: U.S.N.M. 100961. Ten smaller specimens, the largest 35 $\mathrm{mm}$. standard length. Same locality, date and collector as holotype. Numerous other paratypes collected in Étang Saumâtre by Dr. Beebe and Mr. Tee-Van.

Counts and measurements (in $\mathrm{mm}$.) of three finely preserved specimens (holotype and two largest paratypes) in Dr. Bond's series are now given. Standard length 66, 35, 31. Total length 82, 46, 41. Depth 31, 14.5, 13. Head 21, 11, 10. Snout 7, 3.5, 3.5. Eye 6, 4, 3.5. Interorbital 7.5, 3.3, 2.5. Width of operculum $5.5,3.5,3.3$. Least depth caudal peduncle $12,6.3,5.5$. Length penultimate dorsal ray $7.5,5,4.5$. Length third dorsal ray $14,8,7.5$. Predorsal length 37, 19, 17.5. Preorbital width 6, 3, 2.5. Preventral length (to tip lower jaw) $38,19,17$. Length pectoral fin 18, 10, 9. Dorsal says (count) 11, 11, 11. Anal 11, 11, 11. (The dorsal and anal are each usually 11 ; in one specimen they are 12-12, and in another 11-10). Pectoral 17-16, 16-16, 17-17. Pelvic 7, 7, 7. Caudal 7-12-7, 7-12-6, 7-12-7. Scales lateral 
$28+3,30+3,28+4$. Scales transverse (dorsal origin to pelvic origin) 14 , 14,14 . Scales predorsal 11, 11, 12.

In the high scale count this species would seem to agree with the Cuban Cyprinodon felicianus (Poey, 1868, p. 412; Jordan and Evermann, 1896, p. 676). C. felicianus was described from a single specimen which may not now be in existence. Poey's description is incomplete, many points now considered important having been omitted. Breder (1932) has recently included felicianus in that part of his synopsis of West Indian Cyprinodons characterized by the lack of an enlarged humeral scale. Since no specimens have been reported since Poey's time, and the humeral scale was not mentioned in his description, I am at a loss to explain Breder's placement unless he had access to the type or more recent unreported material.

There are two lots of Cuban Cyprinodons received from Poey and labeled as C. felicianus in the United States National Museum (37434 and 37535). None of these specimens agrees with Poey's description in the high scale count, unless one includes the scales on the base of the caudal. However, the single example (male) in lot 37535 is exactly the same (standard) length as that given by Poey for his male holotype. This specimen has 30 scales if one counts a few in front of the upper end of the opercle and on the caudal base behind the hypural, not usually included by modern workers. This specimen may be the holotype, but if it is, felicianus is very close to, or identical with, $C$. variegatus riverendi. Lot 37434 represents the same form. The humeral scale is enlarged and the scales are 25 or 26.

Dr. Luis Howell Rivero has been so kind as to make a search for the type of felicianus in the Museum of Comparative Zoology. He finds no specimen agreeing exactly with Poey's measurement, but there are others, sent by Poey as felicianus, similar in their characteristics to those in the National Museum.

Since the specimens of felicianus in the National and Harvard collections were sent to these two institutions by Poey as representative of his species, I am inclined to accept them as such, in spite of the fact that the type is not certainly recognizable among them. This being the case, I am forced to consider bondi as new, since it in no way closely resembles Poey's specimens. The other West Indian Cyprinodons all have even fewer scales than felicianus.

C. bondi is named for Dr. R. M. Bond, who collected the types during an ecological investigation of the Hispaniolan lakes. The species will be figured and more completely described in my final paper on the cyprinodonts of Hispaniola.

Family PoEciliIdae

Subfamily Gambusiinae

Genus Gambusia Poey

\section{Gambusia dominicensis Regan}

Gambusia dominicensis Regan, 1913, p. 989, pl. 99, fig. 7 (Haiti); Hubbs, 1926, p. 25 (in key; copied).

This species is common in southern Haiti. Dr. Beebe and Mr. TeeVan obtained it in the Cul-de-Sac Plain five miles north of Port-au-Prince and at Étang Saumâtre.

\section{?Gambusia oligosticta Regan}

? Gambusia oligosticta Regan, 1913, p. 988, text-fig. 169B, pl. 99, fig. 1, 2 (Jamaica); Hubbs, 1926, p. 25 (in key; copied). 
I have examined one lot of Gambusias (U.S.N.M. 78247) collected by Mr. J. B. Henderson at Thomazeau, in the Cul-de-Sac Plain of Haiti, which I cannot at present separate from the Jamaican oligosticta. They have the same heavy body and long head and the gonopodial characters are practically identical.

\section{Gambusia beebei, new species}

Diagnosis: A very large species, belonging to the subgenus Gambusia, allied to the Antillean group containing punctata, wrayi, gracilior, and others. In the gonopodium the spines of ray 3 are very long, considerably overtopping the hook of ray 4, the longest spine more than equal to twothirds of the combined basal length of all. The extremely long, heavy head (nearly a third standard length), the long snout (over a third head), and the long, heavy jaws are seen in no other species, although approached by wrayi, from which beebei differs otherwise in the longer spines and their basal segments of ray 3 and in the much more posterior dorsal and anal. No spots or speckling and no suborbital bar present.

MATERIAL: Sixty-four females, 35 to $93 \mathrm{~mm}$. total length, and 3 males, 36 to $58 \mathrm{~mm}$. total length, all obtained at Lake Miragoâne, in the southwestern peninsula of Haiti, by William Beebe and John Tee-Van. The species is known only from this one collection and station.

Holotype: No. 7168, Dept. Tropical Research, New York Zoological Society. Adult male, $47 \mathrm{~mm}$. standard length, $58 \mathrm{~mm}$. total. Étang de Miragoâne, Haiti, S. W. end of lake, from Aux Cayes Road. Apr. 12, 1927. William Beebe and John Tee-Van.

Description of Holotype: Dorsal 9. Scales lateral 31, plus 3 on caudal. Scales predorsal 16.

Head .27.2 Interorbital .08. Eye .09. Snout .095. Maxillary end to tip of lower jaw .115. Depth .22. Peduncle .15. Snout tip to dorsal origin .63. Snout tip to anal origin .49. Height of longest dorsal ray .145. Length of pectoral .18.

Form elongate, pike-like; head very long and pointed, both from above and from side. Lower jaw very prognathous. A flattened continuous curve from snout to dorsal. Body scarcely or not at all angulated. Lower profile behind anal fin slightly convex. Caudal fin with outer rays slightly produced and central margin convex.

Gonopodium .52 of standard length. Segments of enlarged third ray rather short and wide, the 13 distal segments with long spines. Longest spine, with its basal limb, more than two-thirds total basal length of the spine-bearing segments. The central spines all have an elongated lower limb similar to those of G. punctata. The lobe formed by the spines considerably overtops the tips of the two divisions of ray 4 . Elbow of anterior division of ray 4 well developed, composed of 2 segments only partially divided, with two others entering slightly at the proximal base. Segments of anterior branch of ray 4 distal to elbow not coalesced with a ridge-like extension from the elbow. Posterior division of ray 4 with terminal hook and 4 distinct serrae, these not especially long or hooked. Ray 5 below the terminal hook not greatly bowed.

Below yellowish, above brownish. Occiput and midpredorsal line blackish. Chin and sides of lower jaw dusted with black. A fine dark hair-line along middle of whole length of sides, strongest above pectorals,

2 The proportions are given in hundredths of the standard length and are expressed as though taken on an ideal longitudinal axis of the body. This method is not used in the measurements of Cyprinodon bondi, which were taken from point to point, as indicated, with dividers. 


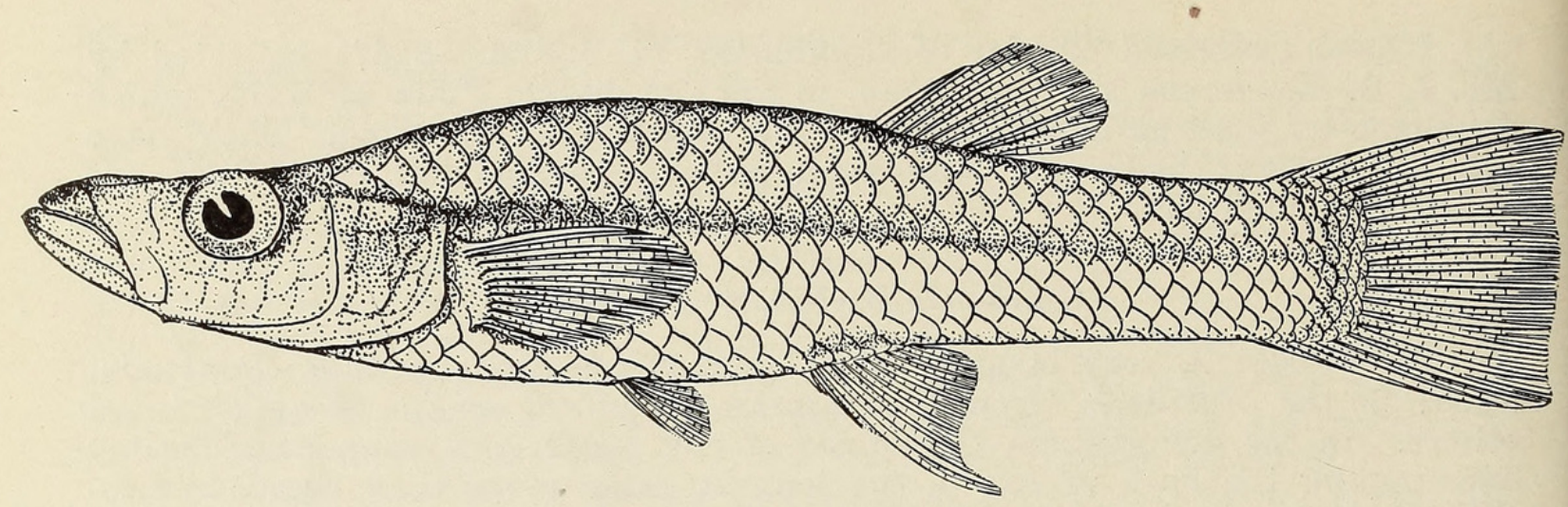

Fig. 273. Gambusia beebei Myers. Old female, paratype, $93 \mathrm{~mm}$. total length.

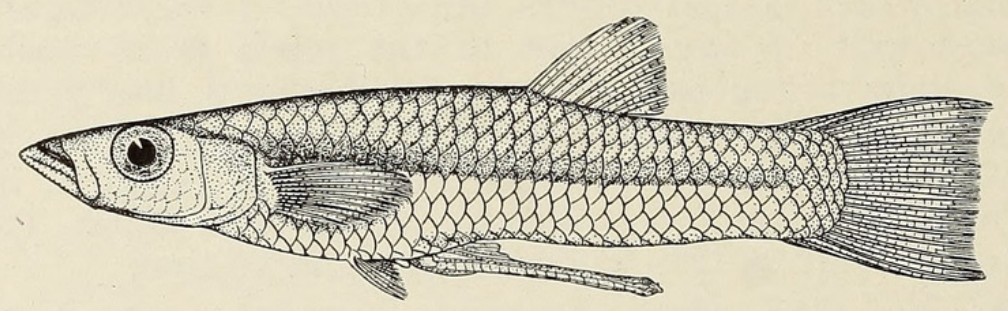

Fig. 274. Gambusia beebei Myers. Adult male, holotype, $58 \mathrm{~mm}$. total length.

weak on tail. Sides above this streak dusky, ${ }^{3}$ with edges of scales heavily dark-edged. No black dots or speckles on sides. No suborbital bar. Fins without speckles, but with faint dusting of dark chromatophores along rays.

Description of Female: No. 7299, Dept. Tropical Research, New York Zoological Society, total length $93 \mathrm{~mm}$. Dorsal 9. Anal 11. Scales lateral $32+3$. Scales predorsal 16 .

Head .30. Interorbital .11. Eye .07. Snout .105. Maxillary end to tip lower jaw, .13. Depth .23. Peduncle depth .12. Snout tip to dorsal origin .66. Snout tip to anal origin .61. Dorsal broken. Length longest anal ray .16. Length pectoral .18.

Form elongate, pike-like; head very long and heavy, jaws somewhat rounded from above. Length of upper lip nearly half eye. Distance from tip of snout to cleft of mouth equal to eye. Width of mouth from cleft to cleft equal to interorbital. Dorsal profile concave to nape, thence shortly convex, the curve straightening to dorsal. Central portion of top of snout raised into a characteristic "nasal boss," not evident in young or halfgrown females. Body not angulated. Anal margin more or less straight after the third and fourth rays, which are prolonged. ${ }^{4}$ Caudal edge slightly convex, the outer rays a little produced. Appressed pectoral fin reaches middle of appressed pelvic fins.

Coloration as in male. ${ }^{5}$

VARIATION: The scales vary but little, lateral 30 or 31 , predorsal 15 or 16 . The dorsal is consistently 9 , varying to 8 in a few. The anal in the female is 10 or 11 . The first two rays and the last are small. The smaller females lack to a large extent the concave profile at the nape

\footnotetext{
3 Too heavily indicated in Fig. 274. In all cases in which the figures disagree with the text, the latter is to be taken as correct.

4 Only the third shown prolonged in the drawing.

5 The figure of the female likewise shows too heavy an indication of a lateral band.
} 
although this is usually somewhat evident. None but the very largest shows the upraised "nasal boss." The largest male (holotype) shows a longer, sharper snout, both from above and from the side, than do the two smaller ones. He further differs from these two in the structure of the gonopodium, the spine-bearing segments of ray 3 being more numerous and the spines and their basal limbs being longer. Further, the suture which in the holotype nearly divides the main segment of the "elbow" of ray 4 into two, has not appeared in these smaller fishes. These facts indicate that after maturity the gonopodium may change with age.

Following are proportions of seven females of graded size, of standard lengths of $64.5,61,53,46,37,35$, and $28.5 \mathrm{~mm}$., respectively. Head .285, $.32, .315, .28, .29, .26, .29$. Interorbital .10, .11, $.11, .10, .11, .11, .10$. Eye $.075, .09, .085, .085, .09, .085, .09$. Snout $.105, .115, .11, .09, .10, .095$, .095 . Snout tip to dorsal origin .68, .67, .66, .68, .66, .65, .67.

Discussion of RELATIONSHIPS: The great size, the elongate form, the large head, the long jaws, the peculiar dorsal profile and nasal boss of the older females, as well as the bodily proportions and the gonopodial structure of the male, set off this species as one of the most distinct in the genus. It has been directly compared with specimens of all of the West Indian Gambusias save melapleura and caymanensis, (neither of which seem at all close) including type material of wrayi, gracilior, oligosticta and manni. It differs widely from all of them in a number of characters.

In Hubbs' key to the species of Gambusia (Hubbs, 1926, p. 21), beebei falls within the subgenus Gambusia on gonopodial characters. It does not, however, agree with the bodily proportions expressed in division $\mathrm{d} 2$, the mouth having a deep lateral cleft, the jaws being rather pointed from above, especially in the male, the width of the head less than the distance from snout tip to posterior border of eye, and the width of the upper jaw being less than the great length of the upper jaw, measured to end of maxillary. Within the subgenus Gambusia, beebei agrees with division h1 of Hubbs' key in having the spines of ray 3 considerably overtopping the terminal hook of ray 4, but differs in that the longest spine is somewhat less in length than the bases of the combined spinous segments.

The three species included in division $\mathrm{h} 1$ by Hubbs are senilis, nobilis and affinis, all inhabitants of southern Texas and northeastern Mexico. I have compared examples of all three with beebei, and there is indeed a remarkable similarity in the gonopodia ${ }^{6}$. The most obvious difference is to be seen in the considerably longer basal limbs of the spines of ray 3 of beebei. Furthermore, the form of the "elbow" of ray 4 differs, and the "serrae" are much less elongate and hooked in the new form. When one comes to the bodily proportions and general appearance, beebei at once shows that it is not closely related to these tiny mainland species. The wide cleft of the mouth, the long snout and jaws, the enormous head, the nasal boss and concave nape of the old females, the color, and, not least, the large size, do not allow us to place beebei near these forms.

Proceeding to other possible relatives, we find the new form differing from Hubbs' group h2 in the length of the spines of ray 3, which overtop the hook of ray 4. This is the group of the subgenus Gambusia confined, with the sole exception of nicaraguensis, to the Antilles. With nicaraguensis, beebei agrees to some extent in the form of the anal of the female, but

6 Our specimens of $G$. nobilis were collected at Phantom Lake, Toyahvale, Texas, by G. M. Kranzthor and the writer, May 21, 1929, and form the first large series of this fish ever collected. Hubbs (1929, p. 2) has redescribed nobilis from a few specimens collected by others near Toyahvale. It will be noted in Regan's figure of the gonopodium of senilis (Regan, 1913, text-fig. 168E) that che spines of ray 3 are of a peculiar straight form, very different from the rather curved shape seen in other species. It is thus of interest that in our large series of nobilis, surely all one species, this straight senilis type of spines is seen in some specimens, while in others a more elongate curved type is present. There are numerous intermediates connecting the two types. 


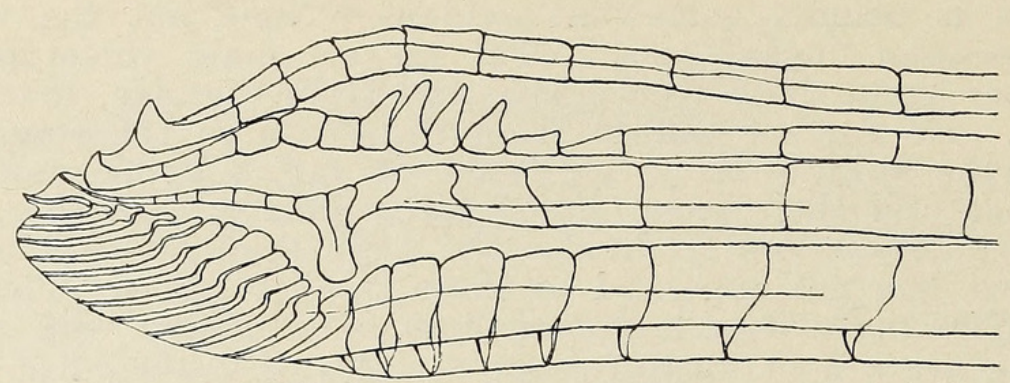

Fig. 275. Gambusia beebei Myers. Distal end of gonopodium of holotype. Camera lucida drawing by G. S. Myers.

differs in all the points mentioned above with reference to senilis, nobilis and affinis as well as the added ones of the lesser depth and lesser compression of the body.

Of the island forms no material of either the Jamaican melapleurn or caymanensis, from Grand Cayman, has been available for comparison. The males of neither are known, and the described females (Regan, 1913, p. 988 and 990 ) are of small size (largest $47 \mathrm{~mm}$. for melapleura and $26 \mathrm{~mm}$. for caymanensis). Very likely both are smaller species than the new one; bee$b e i$ is certainly immature at $26 \mathrm{~mm}$. and probably at $47 \mathrm{~mm}$. also. Specimens of beebei of about $40 \mathrm{~mm}$. show the following apparent differences from melapleura. Dorsal 8 and 9 (versus 11 or 12). Interorbital $1 \frac{1}{2}$ (versus $13 / 4$ ) in head. Dorsal origin midway between caudal base and a point somewhat behind pectoral origin. Least depth of peduncle equals half head. No traces of spots on fins or body. Compared with the description of caymanensis, small females of beebei are seen to differ most significantly in dorsal position, this fin being still further forward in caymanensis than in melapleura, and in interorbital width $\left(1 \frac{1 / 2}{2}\right.$ in head versus 2 to $\left.2 \frac{1}{4}\right)$. 'The color is likewise very different; beebei has no suborbital bar, no series of spots on the dorsal and no markings on the caudal.

There remain seven Antillean species for comparison, manni of the Bahamas, punctata and puncticulata of Cuba, wrayi, oligosticta and gracilior from Jamaica, and dominicensis from Hispaniola itself. Dr. Carl L. Hubbs has been kind enough to compare one of the smaller males and a series of females of beebei with the types of manni. He writes as follows: "The Haiti Gambusia... is certainly not manni. It is a very much larger fish, with a much longer snout (more instead of less than one-third head), slenderer, without trace of suborbital bar and with the barest trace of fin spots and of axial streak."

The figures of the gonopodia of dominicensis, oligosticta, wrayi and. gracilior given by Regan (1913, Text-Figs. 168 and 169) show that none of these species have the spines of ray 3 nearly as long as those of beebei, and it should be particularly noted that in none do these spines have a long, well-developed basal limb, so conspicuous in beebei. Punctata, on the other hand, has the spines of ray 3 long, with a well-developed basal limb, but the gonopodium differs in other ways. In the first place the bowing below the hook of ray 5 is much greater in punctata than in beebei, and secondly the spines of ray 3 , although themselves proportionally almost as long as in the new species, reach scarcely past the hook of ray 4 . These spines, in beebei, are more numerous (12 versus about 9 ) and project much further beyond the hook of ray 4. The greater bowing of ray 5 and the more bunched spines of ray 3 give the tip of the gonopodium of punctata a characteristic thickened, rounded appearance, very different from that of the new species. In form, punctata differs widely from beebei in the much deeper body, shorter

7 See Hubbs, 1927. 
jaws, snout and head, and the presence of rows of spots on the body and fins, as well as in fin counts and fin positions.

The Cuban puncticulata is a small fish, rather variable in its characters, showing little similarity to the new fish. The Jamaican oligosticta, of which I have seen type material received by exchange from the British Museum, is very close to puncticulata and may not be distinguishable. Oligosticta is represented by a so far unreported similar form in Haiti, which is likewise doubtfully distinct from puncticulata. From all three forms beebei differs in the associated characters of very large head, long jaws and snout, as well as in the dorsal position, the general body form and the absence of spots. The long spines and their basal limbs in ray 3 of the gonopodium and the blunt serrae of ray 4 are further differences of note.

Gambusia gracilior, of which I have examined typical material received by exchange from the British Museum, is a small species which, in the very short spines of ray 3 of the gonopodium, shows no close relationship with beebei. The small head, the short jaws and snout, the spotted fins and the small size are distinctive. Dominicensis is close to gracilior and differs in the same way. We have large series of this species, the common Gambusia of Haiti.

With Gambusia wrayi, from Jamaica, beebei shows more similarity than with any other form. It thus has been of value to have at hand two (adult male and female) of Regan's types of wrayi, on loan from the British Museum. For this courtesy I must express the greatest thanks to Mr. J. R. Norman, Assistant Keeper of the Department of Zoology. In the rather large, heavy head, the elongate form, the comparatively large size and the absence of spots, wray $i$ approaches or agrees with beebei, but on comparison of these types of wrayi with specimens of beebei of similar size, numerous differences come to light. In the first place, these smaller females of beebei have not attained nearly their full growth, although some are probably adult. Of course we have no way of telling whether or not wrayi may grow larger than the types, but the two specimens at hand (male $29.5 \mathrm{~mm}$. standard length, female $43 \mathrm{~mm}$.) have the full-bodied appearance of mature Gambusias while beebei of the same size looks slender and immature. Further, these beebei have a longer head (about $3.2 / 5$ versus $32 / 3$ in the standard length), longer snout (which, due to the longer head, is contained in the head length about thrice, as it is in wrayi), much longer jaws, a much more slender head, body and caudal peduncle, and a more posterior dorsal. The heavy, undershot jaw of beebei, with its blackish dusting of chromatophores, distinguishes the specimens at a glance from wrayi.

Another difference has been noted, in a character not hitherto used for the distinction of species of this genus. The frontal and ethmoid region of the top of the head is, in Gambusia, separated from the supraorbital region by a distinct groove on each side which dies out over the center of the orbit and usually runs outward as it approaches the fold separating the premaxillary from the top of the head. This ethmo-frontal area between the two grooves is the region which, in old females of beebei, is upraised into what I have called the "nasal boss." In examining wrayi it is seen that the ethmo-frontal grooves (as we may call these structures) are rather wide apart, slightly converging posteriorly, near their ends, and diverging but little anteriorly. In beebei, on the other hand, the grooves are only about half as far apart, diverging slightly but evenly for a distance, and then flaring suddenly outward as they approach the premaxillary groove. Females of beebei, likewise, have a distinctly narrower interorbital and a sharper lower jaw, viewed from above, than does wrayi.

In gonopodial characters wrayi may be considered to show but little other than a general similarity to beebei. The bowing of ray 5 below the terminal hook appears greater in Regan's figure (Regan, 1913, Text-Fig. 
168b) but in the type in hand this is much less evident. It is in the spines of ray 3 that the greatest differences are observed. In wrayi they are short and scarcely overtop the terminal hook of ray 4, and the basal limb is short and not prolonged. In beebei, even in the smaller males, the spines are much longer, considerably overtopping ray 4, and the long basal limbs are well developed.

Thus, in spite of resemblances to wrayi, it would seem that beebei is an isolated member of the genus Gambusia with no very close relatives among the known forms. Possibly its relationships are to be sought in some yet-to-be-discovered species in Jamaica, in Cuba, or even in Hispaniola.

Since the above was written, Breder (1934) has described Gambusia hubbsi from Andros Island, Bahamas. This small fish is similar to manni, oligosticta and puncticulata, and is not at all closely related to our new form.

HABITS AND HABITAT: This species is known only from the type collection and nothing is recorded of its habits other than that the specimens were obtained with a 20 -foot seine on a sandy beach. Lake Miragoâne is a fresh-water lake.

REMARKS: With punctata of Cuba, this is the largest Gambusia known. Eigenmann (1903, p. 223) has recorded a punctata $92 \mathrm{~mm}$. in length, but whether this includes caudal or not I cannot say. The largest female beebei is $93 \mathrm{~mm}$. total, a very large Gambusia indeed.

I take pleasure in dedicating this interesting species to Dr. William Beebe in recognition of his extensive ichthyological work in Haiti.

\section{Subfamily Poeciliinae \\ Genus Mollienisia Le Sueur}

\section{Mollienisia dominicensis (Evermann \& Clark)}

Platypoecilus dominicensis Evermann and Clark, 1906, p. 852, fig. 2 (San Francisco Mts., Santo Domingo, 40 miles from Santo Domingo City). Limia dominicensis (in part) Regan, 1913, p. 1015 (excluding description and all of synonymy save reference to Evermann and Clark).

Limia caudofasciata (not of Regan) Nichols and Myers, 1923, p. 2 (Lo Bracita, Prov. Pacificador, S. D.).

Mollienisia dominicensis Myers, 1931, p. 2 (Lo Bracita, Prov. Pacificador, S. D.; Artibonite System, Haiti).

Diagnosis: A small Mollienisia with a small dorsal fin, the origin of which is midway between the head (females) or the eye (males) and the caudal base. The normal number of dorsal rays is $81 / 2$ and of anal rays $91 / 2$. The lateral series of scales number 28 to 30 . In the male, the first pelvic ray is short, with a conspicuous, fleshy, clavate tip which is closely attached to a broad bony protuberance of the second ray at the middle of the latter. Gonopodium with the membranous hook of ray 3 and the terminal retrorse segment of the posterior branch of ray 5 well-developed. Ray 3 with more or less well-developed spinous processes on the posterior side, as in M. latipinna. The chief gonopodial difference between this species and $M$. sphenops, $M$. latipinna, and their close relatives lies in the spinous processes of the anterior face of ray 3 . In the other forms these are simple spines. In $M$. dominicensis, on the contrary, these processes are nearly all widely T-shaped or even faintly bifurcate at their tips, only a very few (sometimes only one) of the distal processes being developed as simple spines. Color dark, the scales of the upper parts heavily dark edged. Both sexes with a black spot (stronger in females) at the base of the posterior dorsal rays, the fin darkedged in males. Males with six to ten narrow, blackish, vertical bars, much narrower than the interspaces, from dorsum to venter, beginning above the anal base. Female with faint traces of vertical bars. 


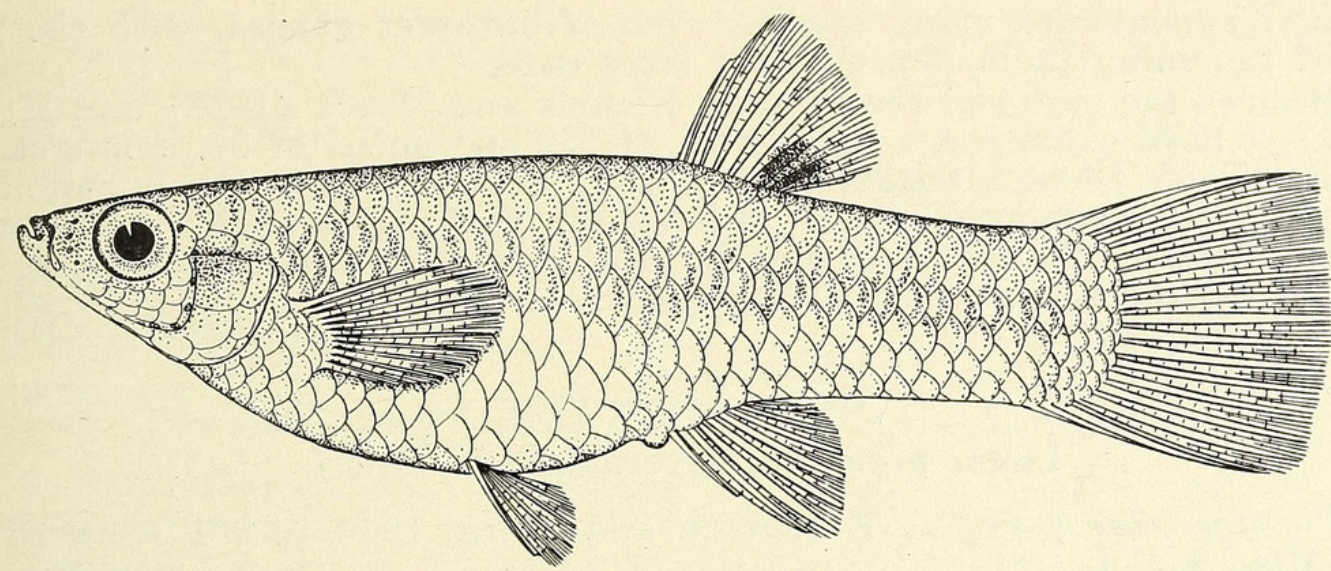

Fig. 276. Mollienisia dominicensis (Evermann and Clark). Adult female, L'Atalaye Plantation, Haiti. Twice natural size.

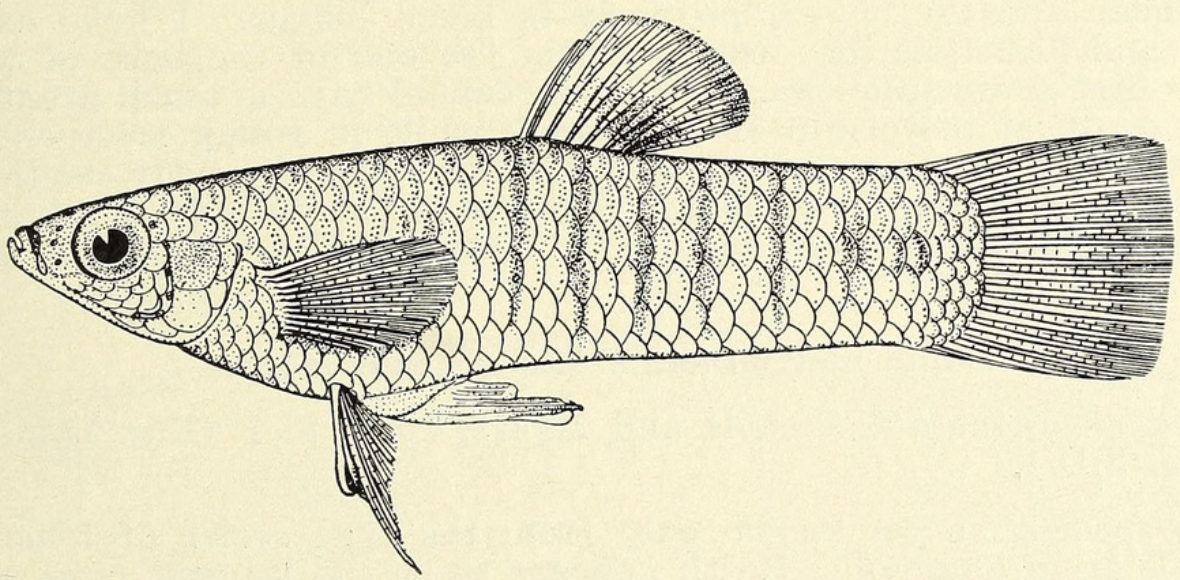

Fig. 277. Mollienisia dominicensis (Evermann and Clark). Adult male, L'Atalaye Plantation, Haiti. Twice natural size.

The rather striking differences between this species and others in the genus Mollienisia, particularly in the gonopodium, lead me to propose the new subgenus Psychropoecilia, genotype Platypoecilus dominicensis, the name being in allusion to the clear mountain torrents which are the habitat of the species.

This is the species described by Evermann and Clark (1906) as Platypoecilus dominicensis. However, the confusion which has arisen since Regan erroneously synonymized the species with Limia dominicensis (Cuvier and Valenciennes) leads me to believe that it would be much better to rename the Mollienisia. Further, according to one interpretation, Jordan and Clark's name, having once been sunk as a homonym (and synonym) of Limia dominicensis (Cuvier and Valenciennes), cannot be resuscitated. I submitted the facts to Dr. C. W. Stiles, Secretary of the International Commission of Zoological Nomenclature, for his private opinion, and he assures me that, under a strict application of the Rules, the species must be renamed. In spite of the fact that I believe the renaming of Evermann and Clark's species would clarify the situation, I cannot subscribe to the view that the mere synonymizing of a species with another bearing an identical specific name is sufficient cause for renaming the species of later date. General acceptance of such procedure would leave the way open for anyone to (erro- 
neously) synonymize many species, even of different genera, with the motive of renaming them himself at a later date.

Besides the material recorded by Nichols and Myers (1923) and Myers (1931), I have examined a fine series of 250 specimens of $M$. dominicensis (U. S. N. M. 88884, 100286, and 100287) collected in a small mountain stream, in the Artibonite system, at l'Atalaye Plantation, about 3 miles west of San Michel, Haiti, during March, 1928, by A. J. Poole, as well as the holotype of the species in the National Museum.

\section{Genus Limia Poey \\ Limia perugiae (Evermann \& Clark)}

Platypoecilus perugiae Evermann and Clark, 1906, p. 851 (San Francisco Mts., S. D.).

Limia perugiae Myers, 1925, p. 371 (name only).

This species, which is still known only from a single female specimen, is probably a Limia. It appears to be very close to $L$. melanonotata but it is more slender and the caudal peduncle is much longer. I have examined the type and find that the distance from the end of the base of the anal fin to the first short supplementary lower caudal rays is much greater than the body depth at the origin of the dorsal, while in young melanonotata of the same size this measurement is much less than the body depth at the dorsal origin. Further, perugiae was taken in the mountains of southeastern Santo Domingo, while melanonotata is essentially a fish of the lowlands of Haiti.

\section{Limia melanonotata Nichols and Myers}

Limia melanonotata Nichols and Myers, 1923, p. 1 (Las Lajas, on L. Saumâtre, S.D.).

This species, as yet known only from the type series of females and one female from Maneville, Haiti, appears to be the largest, most striking, and most abundant Poeciliid of the Cul-de-Sac Plain. It is a deep-bodied fish very close to $L$. nigrofasciata Regan, but is distinguished by a number of characters. The younger females are marked with a few series of black spots down the middle of the sides which fade out slightly in the full grown adults of $60 \mathrm{~mm}$. standard length. The male, which never develops the peculiar humpbacked profile of adult nigrofasciata, has a high, black dorsal fin and a yellow caudal with a wide, black, terminal border. There are several narrow, vertical, dark bars on the posterior part of the body.

The finest and largest specimens I have seen were the series taken in Source Trou Caiman by Dr. A. W. Herre and Dr. R. M. Bond..

Dr. Beebe and Mr. Tee-Van secured this species in great abundance in Etang Saumâtre, and from a locality 5 miles north of Port-au-Prince.

\section{Limia nigrofasciata Regan}

Limia nigrofasciata Regan, 1913, p. 1015, pl. 101, fig. 1, 2 (Miragoâne, Haiti); Nichols and Myers, 1923, p. 1 (Las Lajas, S.D.; Maneville, Haiti).

Limia arnoldi Regan, 1913, p. 1016, pl. 101, fig. 5 (Miragoâne, Haiti).

Through the courtesy of Mr. J. R. Norman of the British Museum I have been able to examine two of Regan's types of Limia arnoldi, and I am fully in agreement with Rachow $(1914$, p. 194, footnote 8) that the species was based on subadult examples of nigrofasciata. Regan's material of arnoldi and nigrofasciata consisted of aquarium specimens sent to him by 
Rachow and by J. P. Arnold, the two distinguished aquarists of Hamburg. These men knew this species well in aquaria and Rachow's opinion was certainly to be relied on.

Nigrofasciata is a very variable species, as shown by the large series I have examined, and the younger adult males are very different from the old humpbacked individuals such as the one Regan figured.

The species is abundant in the Cul-de-Sac Plain and about Etang Saumâtre. Beebe and Tee-Van obtained a fine series at Lake Miragoâne, the type locality.

\section{Limia dominicensis (Cuvier and Valenciennes)}

Poecilia dominicensis Cuvier and Valenciennes, 1846, p. 131, pl. 526, fig. 1 (Santo Domingo).

Limia dominicensis (in part) Regan, 1913, p. 1015 (on type material; excluding types of Poecilia melanogaster and Platypoecilus dominicensis Evermann and Clark in synonymy).

This species was the first Poeciliid known from Hispaniola, although judging from the material I have seen, it is one of the rarest. Regan had two of Cuvier and Valenciennes' types, and he referred Günther's five female types of Poecilia melanogaster to the species, as well as including Evermann and Clark's Platypoecilus dominicensis. The latter is, as indicated above, a Mollienisia. Through the courtesy of Mr. J. R. Norman, I

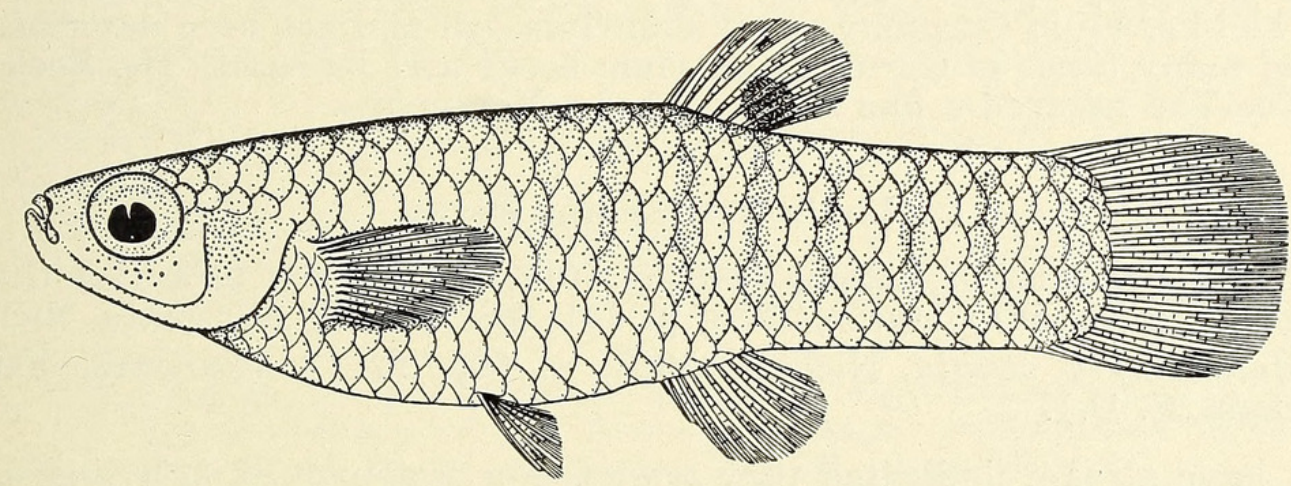

Fig. 278. Limia dominicensis (Cuvier and Valenciennes). Female type (cotype) of Poecilia dominicensis Cuvier and Valenciennes. $2 \frac{1}{2}$ times natural size. The cheek and opercular scales have fallen off the specimen.

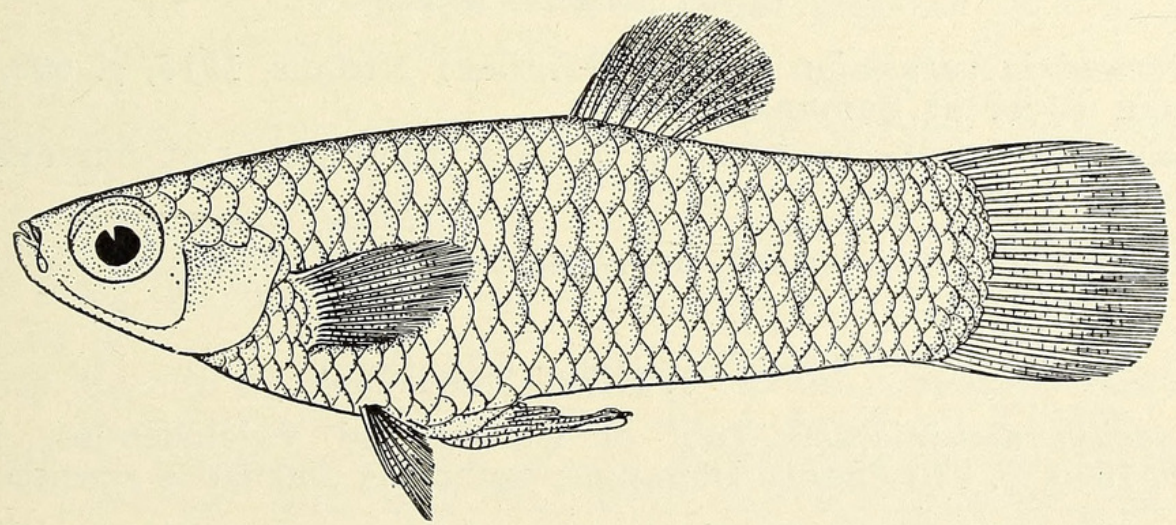

Fig. 279. Limia dominicensis (Cuvier and Valenciennes). Male type (cotype) of Poecilia dominicensis Cuvier and Valenciennes. $21 / 2$ times natural size. The cheek and opercular scales have fallen off the specimen. 
have been able to examine one of the types of melanogaster and to compare it with a male and female from the type lot of Poecilia dominicensis Cuvier and Valenciennes, received by exchange from the Paris Museum through the good offices of Dr. J. Pellegrin. (These two types of dominicensis are now U.S.N.M. 94584.) I have no hesitation in pronouncing melanogaster to be a different species. The type locality of melanogaster is not certainly known, but Günther (1866, p. 346) thought the types might be from Jamaica. The type examined by me seems to be the same as a Jamaican Limia very close to $L$. caudofasciata Regan. Limia melanogaster is then, a Jamaican fish ${ }^{8}$ differing from caudofasciata chiefly in the stouter body, the coloration, and the very large, black "pregnant spot" developed by the females. Males of melanogaster frequently have a smaller black spot in the same position!

The only examples of Limia dominicensis yet known appear to be the types, from an unknown locality in Santo Domingo. The two I have seen are small fish, with the color much faded. There are seven or eight faint vertical bars, similar to those of nigrofasciata and the female has a black spot at the base of the posterior dorsal rays. The body is fairly elongate and the dorsal of the male is not enlarged.

\section{Limia ornata Regan}

Limia ornata Regan, 1913, p. 1016, pl. 101, fig. 7 (Haiti).

This boldly spotted species was described from five females. It has been well known in Germany as an aquarium fish and has been described and figured many times in German aquarium books and journals. Dr. Beebe and Mr. Tee-Van secured a fine series at Lake Miragoâne.

\section{Limia heterandria Regan}

Limia heterandria Regan, 1913, p. 1017, pl. 101, fig. 3, 4 (La Guayra, Venezuela, in error); Myers, 1925, p. 371 (on type of H. zonata Nichols),

Heterandria zonata Nichols, 1915, p. 603, fig. 3 (Sanchez, Samaná Peninsula, S. D.).

I have already indicated that zonata is a synonym of heterandria and that the type locality of the latter species, which was based on aquarium specimens from Germany, must be incorrect.

\section{Limia nicholsi Myers}

Heterandria versicolor (not of Günther) Nichols, 1915, p. 603, fig. 1, 2 (San Juan River at Samaná, S. D.).

Limia nicholsi Myers, 1931, p. 1 (San Juan River at Samaná, S. D.; on Nichols' material).

This species is known only from the types.

\section{Limia versicolor (Günther)}

? Poecilia dominicensis (not of Cuvier and Valenciennes; in part) Günther, 1866, p. 346 (Santo Domingo; excluding Barbados specimen).

8 This fish has been described and figured as a new species, Limia tricolor, by Stoye (1933). It is also mentioned and figured by Stoye $(1935$, p. 65 , pl. 14) and by Innes (1935, p. 298, fig.). Stoye mentioned no types in his original description, but examples have been deposited by him in the Museum of Zoology, University of Michigan. 
Girardinus versicolor Günther, 1866, p. 352 (Santo Domingo).

? Poecilia (Acropoecilia) tridens Hilgendorf, 1889, p. 52 (Port-auPrince, Haiti).

Limia versicolor Regan, 1913, p. 1017, text-fig. 173E (Santo Domingo).

I am not at all sure that Hilgendorf's Poecilia tridens refers to this species. I have seen only three specimens certainly referable to versicolor. They were collected by $\mathrm{Dr}$. Beebe and Mr. Tee-Van at Source Mariani, Haiti.

BREDER, C. M., JR.

\section{LITERATURE CITED}

1932. An annotated list of fishes from Lake Forsyth, Andros Island, Bahamas, with descriptions of three new forms. Amer. Mus. Novit., No. 551, pp. 1-8, figs. 1-3.

1934. A new Gambusia from Andros Island, Bahamas. Amer. Mus. Novit., No. 719 , pp. 1-3, figs. 1-2.

Cuvier, G., and Valenciennes, A.

1846. Histoire naturelle des poissons. Vol. 18.

EigenmanN, CaRL H.

1903. The fresh-water fishes of Western Cuba. Bull. U. S. Fish Comm., vol. 22,1902 , pp. 211-236, pls. 19-21.

EvermanN, B. W., and Clark, H. W.

1906. New fishes from Santo Domingo. Proc. U. S. Nat. Mus., vol. 30, pp. 851-855, fig. 1-3.

GüNTHER, A.

1866. Catalogue of the fishes in the British Museum. Vol. 6.

HILGENDORF, F.

1889. Ueber eine Fischsammlung von Haiti, welche 2 neue Arten, Poecilia (subg. n. Acropoecilia) tridens und Eleotris maltzani, enthält. Sitzb. Gesel. Naturf. Freunde, Berlin, 1889, pp. 51-55.

HUBBS, CARL L.

1926. Studies of the fishes of the order Cyprinodontes. VI. Material for a revision of the American genera and species. Misc. Publ., Mus. Zool., Univ. Michigan, No. 16, pp. 1-87.

1927. Studies of the fishes of the order Cyprinodontes. VII. Gambusia manni, a new species from the Bahamas. Copeia, No. 164, pp. 61-66.

1929. Studies of the fishes of the order Cyprinodontes. VIII. Gambusia gaigei, a new species from the Rio Grande. Occ. Pap. Mus. Zool., Univ. Michigan, No. 198, pp. 1-11.

INNES, W. T.

1935. Exotic aquarium fishes, a work of general reference. 1st ed. Philadelphia.

JoRdAN, D. S., and EvermanN, B. W.

1896. The fishes of North and Middle America. Bull. U. S. Nat. Mus., MYERS, G. S. No. 47, vol. 1.

1925. Results of some recent studies on the American killifishes. The Fish Culturist, Philadelphia, vol. 4, No. 8, pp. 370-371.

1927. An analysis of the genera of Neotropical killifishes allied to Rivulus. Ann. Mag. Nat. Hist., Ser. 9, vol. 19, pp. 115-129.

1931. Poeciliid fishes of the genus Mollienisia in Hispaniola, with notice of a new Limia from the Samaná Peninsula. Amer. Mus. Novit., No. 503 , pp. 1-2. 
NICHOLS, J. T.

1914. Gobiosoma longum and Rivulus heyei, new fishes from the West Indian fauna. Bull. Amer. Mus. Nat. Hist., vol. 33, pp. 143-144, 1 fig.

1915. On Heterandria zonata sp. nov. and Heterandria versicolor (Günther) from the island of San Domingo. Bull. Amer. Mus. Nat. Hist., vol. 34, pp. 603-604, figs. 1-3.

NiCHOLS, J. T., and Myers, G. S.

1923. A new Limia from San Domingo. Amer. Mus. Novit., No. 79, pp. 1-2.

PoEy, F.

1868. Synopsis Piscium Cubensium. Repertorio Fisico-Naturale Isl. Cuba, vol. 2, pp. 279-484.

RACHOW, A.

1914. Zur Nomenklatur unserer viviparen Zahnkarpfen (Poeciliinae), nebst Bemerkungen über einige neue Arten. Blätt. für Aquarienund Terrarienkunde, vol. 25, No. 11, pp. 185-199, fig. 1-22.

REgan, C. TATE

1913. A revision of the Cyprinodont fishes of the subfamily Poeciliinae. Proc. Zool. Soc. London, 1913, pp. 977-1018, pls. 99-101.

STOYe, F. H.

1933. A new steel-blue Limia from Jamaica. The Home Aquarium Bulletin, East Orange, New Jersey, vol. 3, no. 6, August, 1933, pp. 12-14, 1 Text-fig.

1935. Tropical fishes for the home, their care and propagation. 2nd ed., New York. 


\section{$2 \mathrm{BHL}$ Biodiversity Heritage Library}

Myers, George S. 1935. "An annotated list of the Cyprinodont fishes of His-paniola, with descriptions of two new species." Zoologica: scientific contributions of the New York Zoological Society 10(3), 301-316. https://doi.org/10.5962/p.190328.

View This Item Online: https://www.biodiversitylibrary.org/item/207852

DOI: https://doi.org/10.5962/p.190328

Permalink: https://www.biodiversitylibrary.org/partpdf/190328

\section{Holding Institution}

Smithsonian Libraries

\section{Sponsored by}

Biodiversity Heritage Library

\section{Copyright \& Reuse}

Copyright Status: In Copyright. Digitized with the permission of the rights holder

Rights Holder: Wildlife Conservation Society

License: http://creativecommons.org/licenses/by-nc/3.0/

Rights: https://www.biodiversitylibrary.org/permissions/

This document was created from content at the Biodiversity Heritage Library, the world's largest open access digital library for biodiversity literature and archives. Visit BHL at https://www.biodiversitylibrary.org. 